\title{
From arsenic to DDT: Pesticides, Fascism and the invisibility of toxic risks in the early years of Francoist Spain (1939-1953)
}

\author{
Silvia Pérez-Criado ${ }^{1}$ and José Ramón Bertomeu Sánchez ${ }^{2}$ \\ Institut Interuniversitari López Piñero, Universitat de València \\ 1e-mail: silprz92@gmail.com \\ ORCID iD: https://orcid.org/0000-0003-1397-4667 \\ 2 e-mail: jose.r.bertomeu@uv.es \\ ORCID iD: http://orcid.org/0000-0003-2040-4507
}

Submitted: 1 April 2020. Accepted: 15 June 2020.

\begin{abstract}
This paper reviews the way in which Spanish agriculture climbed onto the pesticide treadmill. We claim that Fascist policies and expert advice assembled in the early 1940s accelerated the introduction of pesticides into Spanish agriculture and promoted the emergence of the Spanish pesticide industry in the times of autarky. Agricultural engineers were the key protagonists in this process, but other human and non-human actors also played a pivotal role: a new pest (the Colorado beetle), Francoist politicians, farmers, landowners and industry managers. Our focus is on the use of pesticides against the Colorado beetle (the main threat to the potato crop), and the transition from arsenical pesticides to DDT during the 1940s. We discuss how the politics of autarky offered new opportunities for developing agronomic programmes and the chemical industry and led to the creation of the Register of Pesticides in 1942. We also discuss the role of these regulations in concealing the risks of pesticides from farmers and food consumers. Arsenic pesticides became sources of slow poisoning and tools for social control while reinforcing the alliance of agricultural engineers and Fascist politicians in their autarkic and authoritarian projects. When DDT arrived in Spain, the agricultural engineers praised the low toxicity it had demonstrated (compared to lead arsenate) in its first uses in public health and in military campaigns in Italy. Indeed, the data concerning its potential dangers disappeared from view thanks in part to a large multimedia campaign launched to promote the introduction of the new organic pesticides in Spanish agriculture, which is described at the end of the paper.
\end{abstract}

KEYWORDS: Pesticides; DDT; Lindane; Colorado beetles; Pest control; Francoist regime; Agriculture engineers; Toxic risks.

Citation / Cómo citar este artículo: Pérez-Criado, Silvia and Bertomeu Sánchez, José Ramón (2021) "From arsenic to DDT: Pesticides, Fascism and the invisibility of toxic risks in the early years of Francoist Spain (1939-1953)". Culture \& History Digital Journal, 10 (1): e004. https://doi.org/10.3989/chdj.2021.004

RESUMEN: Del arsénico al DDT: Plaguicidas, fascismo y la invisibilidad de los riesgos tóxicos en los primeros años de la España franquista (1939-1953). - Este artículo revisa la forma en que la agricultura española entró en el círculo vicioso de los pesticidas. A principios de la década de 1940, la unión de políticas de inspiración fascista y el asesoramiento de expertos aceleraron la introducción de los pesticidas en la agricultura, y promovieron el surgimiento de la industria española de pesticidas durante los años de la autarquía franquista. Los protagonistas clave en este proceso fueron los ingenieros agrícolas, pero también otros actores humanos y no humanos jugaron un papel fundamental: una nueva plaga (la del escarabajo de la patata), políticos franquistas, agricultores, propietarios de tierras y empresarios de la industria. El trabajo se centra en el uso de pesticidas contra el escarabajo de la patata (la principal amenaza para el cultivo de patata) y la transición del uso de pesticidas arsenicales al DDT durante la década de 1940. La política de la autarquía ofreció nuevas oportunidades para desarrollar programas agronómicos y la industria química y condujo a la creación del Registro de plaguicidas en 1942. También se revisa el papel de estas regulaciones para ocultar los riesgos de los plaguicidas a agricultores y consumidores. Los pesticidas 
con arsénico se convirtieron en fuentes de envenenamiento lento y herramientas para el control social al tiempo que reforzaron la alianza de ingenieros agrícolas y políticos fascistas en sus proyectos autárquicos y autoritarios. Cuando el DDT llegó a España, los ingenieros agrícolas elogiaron la baja toxicidad que había demostrado (en comparación con el arseniato de plomo) en sus primeros usos en salud pública y en campañas militares en Italia. De hecho, los datos sobre sus peligros potenciales apenas tuvieron visibilidad, gracias en parte a una gran campaña multimedia lanzada para promover la introducción de los nuevos pesticidas orgánicos en la agricultura española, la cual se describe al final del artículo.

PALABRAS CLAVE: Plaguicidas; DDT; Lindano; Escarabajo de la patata; Control de plagas; Régimen franquista; Ingenieros agrónomos; Riesgos tóxicos.

Copyright: () 2021 CSIC. This is an open-access article distributed under the terms of the Creative Commons Attribution 4.0 International (CC BY 4.0) License.

\section{INTRODUCTION}

Pesticides have been applied for centuries, but several factors encouraged a more intensive usage during the twentieth century: the international trade of seeds and crops, the expansion of monoculture, and the new motorized transports. At the turn of the twentieth century, arsenic compounds were commonly used in many parts of the world, and since the end of the Second World War, synthetic pesticides have been essential elements of the intensification of agriculture and the so-called "Green Revolution"; they have created new interconnections between capital, labour, materials, transportation networks, food markets and expert knowledge. As with other pollutants, the advent of new pesticides ushered in a new, unequal distribution of human and environmental hazards which depended on their material features, their degree of toxicity and their wide range of uses in different social and cultural contexts. The circulation of the new pesticides also created narratives and discursive practices which were embedded in these conflicts. This last point is the main focus of this paper, which deals with the introduction of DDT in Spain during the first decade of the Francoist dictatorship.

We understand pesticides as sociomaterial products which have both a material and a political dimension. ${ }^{1}$ The early decades of the Franco regime provide an excellent context for exploring these features. Before the 1940s, agricultural engineers frequently lamented the limited use of agrochemicals in Spain. Along with the irrigation problems and the lack of investment in machinery, the issue was regarded as one of the reasons for the low productivity in Spanish agriculture. The first years of the Franco regime were marked by an intensive use of pesticides and the creation of new regulations for encouraging the local pesticide industry, along with campaigns promoting the use of the new agrochemicals. In previous work, we have explored the early history of pesticides before the arrival of DDT, notably the arsenical compounds which were widely used in agriculture during the first half of the twentieth century. We have explored their role in the emergence of the early Spanish pesticide industry, thanks to the modernizing projects designed by agricultural engineers and the autarkic policies of the early Francoist years. As in other examples studied by historians, agricul- tural engineers were key protagonists in this process, but other human and non-human actors also played a pivotal role: the Colorado beetle, Francoist politicians, farmers, and landowners (Bertomeu Sánchez, 2019b).

We start with a brief review of the historiographical issues raised by pesticides in the early twentieth-century Spain. We then explore the challenges created by the arrival of the Colorado beetle in the late 1930s. We provide a collective portrayal of the community of agricultural engineers and their role in the early years of the Franco regime. We discuss how the politics of autarky offered new opportunities for developing agronomic programmes for pest control and the agrochemical industry. We also describe the first important regulation on pesticides, the National Register created in 1942, and draw on this source to review the main producers of DDT and other related pesticides in Spain during the 1940s. We then present an overview of the new discursive practices promoting the use of DDT in academic studies, in publications aimed at the farming industry, and in advertisements in newspapers. We highlight both features that reflect a continuity with earlier discourses (for example, military metaphors, patriotic sentiment, economic profit) and new trends connecting organochlorine pesticides with safety, health, scientific progress and national pride. The new organochlorine pesticides were introduced in Spain in the mid-1940s at a time when the Franco regime was implementing new domestic and international policies in the aftermath of the Second World War, and when the potential role in postwar society of wartime innovations such as DDT and penicillin was becoming clear.

Our claim is that Francoist policies and expert advice assembled in the early 1940s accelerated the introduction of arsenical pesticides in Spanish agriculture and the emergence of the Spanish pesticide industry. Arsenical pesticides paved the way for the arrival of new products such as DDT and mapped out Spain's later route towards what Robert van den Bosch called the "pesticide treadmill" - that is, the marginalization of other forms of pest control and the creation of new balances between shortterm profits and long-term human and environmental costs (Bosch, 1989; Murray, 1994; Wright, 2005).

Unlike arsenical pesticides, DDT was a new organic product associated with the successful wartime campaigns against typhus and malaria. Unlike arsenic, DDT 
was not associated with cases of poisoning or accidents, so the new product was promoted as a "safe" alternative to the old pesticides which had been so rapidly introduced during the early 1940s. The new product was used in public health campaigns against malaria and typhus, in agriculture against pests such as the Colorado beetle, and in household cleaning and spraying against insects. So DDT was presented as a miraculous chemical discovered in wartime which could enhance crop productivity, create economic profit, improve human health, and increase domestic comfort. The focus in this paper is on its first uses in agriculture, particularly in the campaigns against the Colorado beetle, in which arsenical pesticides had been previously used. In later papers, we plan to discuss the changing processes of visibilization/invisibilization of toxic hazards in other settings: the food market, public health, and the environment. Our aim is to discuss issues related to the practices of agnotology and undone science, along with role of pesticides and pest control in authoritarian regimes such as the Franco dictatorship (Proctor and Schiebinger, 2008; Frickel et al., 2010; Boudia and Jas, 2014; Henry, 2017; Boudia et al., 2018).

\section{AGRICULTURE, SCIENCE AND FASCISM}

Early twentieth-century Spanish agriculture has been described by historians as backward and unproductive, in part due to the limited use of machinery and agrochemicals. ${ }^{2}$ Recent research in the history of Spanish agriculture has challenged these received views by taking into account a broad range of issues, including environmental constraints, regulatory frameworks, additional historical actors, social decision-making processes, and the regional variations which shaped the introduction of new seeds, technologies and practices in the Iberian Peninsula. ${ }^{3}$ Today, many historians agree that substantial technological changes were introduced in Spanish agriculture during the first decades of the twentieth century. However, the first decade of the Franco regime is still regarded as "the years of delay" or a period of "decline". Lourenzo Fernández has described these years as the "Francoist technological black out" ("apagón tecnológico del franquismo"). He claims that the Civil War and the brutal repression that ensued led to the destruction of the economic, social and institutional bases which had prompted agriculture innovations during the previous three decades. New institutions set up in the early 1940 s, such as the Instituto Nacional de Investigaciones Agrarias (INIA), were attempts to establish a more centralized network of experimental stations and provincial agronomic offices, while consigning earlier projects to oblivion. According to Fernández, the new campaigns for improving agrarian technology were marked by more authoritarian practices, the marginalization of peasants and a renewed role for landowners as the main beneficiaries of the projects. The result was two decades of "black out" (apagón) which put an end to the early twentieth-century technological developments in agriculture or delayed their implementation until the 1960s, when new economic policies were implemented in
Spain and the Green Revolution was adopted (Fernández Prieto and Pujol, 2001; Fernández Prieto, 2007).

While serving as an inspiration for new studies, this framework has been revisited in some sense by recent research on science, agriculture and fascism, particularly by the studies on the importance of science and technology in the making of the early Francoist regime. Historians of agriculture have shown that the agricultural sector played a primary role in different Fascist (or Fascistized) regimes from the point of view of the policies of autarky (self-sufficiency and national independence from external markets) and the strong ruralist discourse at the ideological level, in which the peasantry and the countryside were conceived as the bearers of crucial cultural, demographic and social values for the nation. ${ }^{4}$ Well-known examples of these campaigns are the Battaglia di Grano (the Battle for Grain) in Fascist Italy or the breeding programmes for producing pigs in Nazi Germany (Bonneuil and Thomas, 2010; Saraiva and Wise, 2010; Saraiva, 2016).

Recent studies have also offered a renewed picture of the role of science and technology under Franco, highlighting the relevance of important projects in irrigation, agriculture or construction materials in the making of the authoritarian regime. The policy of autarky played an important role both as a Fascist ideological goal (i.e., self-sufficiency) and as a response to the specific economic situation (i.e., Spain's commercial isolation) caused by the shortage of imported raw materials. Many Francoist politicians were persuaded that self-sufficiency could only be obtained by means of a centralized authoritarian system able to enforce more effective practices in agriculture, while encouraging the intensive exploitation of national resources and an accelerated development of national industry. ${ }^{5}$

\section{AGRICULTURAL ENGINEERS AND THE EARLY FRANCO REGIME}

As in other similar regimes, agricultural engineers played a major role in the developments just mentioned. After the emergence of their profession in the nineteenth century, by around 1930 Spanish agricultural engineers had established their position as key actors in the country's development, playing an important role in the National Institute for Agronomic Research and in many research field stations and dominating a large network of provincial agricultural sections. By the mid-1930s, around 400 agricultural engineers held leading positions the government hierarchy: apart from pest control, they tested new fertilizers, performed experiments on plant breeding, introduced new seeds and promoted new machinery in agriculture. They regarded these issues as the key ingredients for the "modernization" of Spanish agriculture (Pan-Montojo, 2005).

During the 1920s and 1930s, agricultural engineers worked together with forest experts and entomologists from the Museum of Natural History in various areas of pest control. In 1935 an international meeting on entomology was held in Madrid, in which papers on biologi- 
cal and chemical methods of pest control were discussed. The Civil War and the brutal repression that followed affected the communities dealing with pest control in very different ways. ${ }^{6}$ While famous entomologists such as Cándido Bolivar were forced into exile, most of the agricultural engineers remained in Spain and were able to pursue successful careers in the public sector. Many of them celebrated the end of the Republic and cooperated enthusiastically with the new regime. Indeed, two agriculture ministers in early Francoist governments, Carlos Rein Segura and Rafael Cavestany, were agricultural engineers, while the head of the service of agriculture, Manuel Goytia Angulo, was a leading member of both the Falange and the Spanish parliament. As stated above, the reform of the National Institute of Agronomic Research in early 1940 established a large, centralized network under the control of agricultural engineers, comprising experimental farms, phytopathological stations, horticultural centres, agro-chemistry laboratories and research stations (Fernández Prieto, 2007).

Like other "Franco engineers", agricultural engineers had many opportunities to develop their modernization projects in Spanish agriculture. ${ }^{7}$ At the same time, they helped to bolster the new authoritarian regime thanks to the expert advice they provided in irrigation, transportation and agriculture. The marginalization of other groups such as the entomologists of the Museum of Natural History paved the way for the increased use of pesticides at the expense of other forms of pest control. And these trends were exacerbated by the arrival of a non-human protagonist: the Colorado beetle, which posed a major threat to potato yields, one of Spain's most important crops. ${ }^{8}$

\section{LEAD ARSENATE AND THE COLORADO BEE- TLE}

Lead arsenate had already been applied against a variety of pests during the early twentieth century, but its use remained limited until the 1940s, when the Colorado beetle arrived in the Iberian Peninsula. The first case was detected in northern Catalonia, near the Pyrenees, during the summer of 1935. It was contained during the first years but the Civil War dramatically reduced the human and material resources for pest control and the Colorado beetle spread southwards, and its presence was declared a "public calamity" in the summer of $1940 .{ }^{9}$

With the help of the political authorities, agricultural engineers carried out a large-scale campaign against the Colorado beetle. The Servicio de Defensa Sanitaria del Cultivo de la Patata was set up in 1940 under the supervision of the agricultural engineer Agustín Alfaro Moreno (Bajo Mateos, 1946). The new service coordinated an extended network of agriculture offices and laboratories created during the previous decades. The campaigns included talks, practical courses, leaflets, articles in newspapers, radio broadcasts and even documentary films. Services of surveillance were established to detect new foci, and pesticides and spraying equipment were distributed either free or at low prices. The campaigns reinforced the use of pesticides and at the same time extended the state's control over farmers' lives, thanks to the efforts of the provincial network of agricultural engineers (Bertomeu Sánchez, 2020).

As agronomic research provided new ways to manage rural areas, the Franco regime offered new opportunities for agricultural engineers in pest control activities. Apart from the examples mentioned, further regulations were published by the Department of Agriculture in 1944. Landowners, farmworkers, agricultural engineers, municipal authorities and even the Guardia Civil were instructed to carefully survey potato fields and report any trace of the pest as soon as possible. Penalties were imposed on farmers who did not report the pest or did not follow the procedures stipulated. ${ }^{10}$

In the pest control campaigns, the agriculture engineers worked together with the "Hermandades de Labradores y Ganaderos", a sort of Falangist peasant trade union. The union provided spraying equipment and pesticides at low cost or for free and promoted their use in Spanish agriculture. In June 1945, during a large political meeting of the Falange in Madrid attended by leading figures in the regime, members of the Hermandades were provided with "200 sprayers in order to combat potato beetles" under the supervision of agriculture engineers. They marched proudly, with sprayers in their backs, while singing Fascist anthems. ${ }^{11}$

When agrochemical propaganda and Fascist parades were not enough, the regime resorted to political terror and ruthless repression. For instance, in Burgos, in the knowledge that many farmers had not followed the guidelines in previous campaigns, the Gobernador Civil published orders in newspapers announcing that all infringers would be punished most severely, including village mayors who failed to report their fellow farmers. He announced that they would be interned in "concentration camps", their crops confiscated by the government, and their lands offered to other more obedient country folk. ${ }^{12}$

Farmers who were reluctant to use arsenical pesticides were subjected to propaganda campaigns, and in the worst cases to terror and repression. Many of them had grave doubts about the effectiveness of these treatments, the costs involved in terms of chemicals, apparatus and labour and the danger to cattle, in particular on small farms. Hunters were also indignant at the effects of arsenates on wild fauna and some protests were published in newspapers. Moreover, arsenate pesticides were also associated with the horrifying images of accidental or criminal poisoning cases which were becoming more common due to the growing presence of these products in rural life (Bertomeu-Sánchez, 2019b).

\section{THE EARLY YEARS OF DDT IN SPAIN}

This, then, was the background to the introduction of DDT in Spain. In the early 1940s, arsenical pesticides were extensively used. DDT had been synthesized many decades before, but its properties as a pesticide only became known during the Second World War, thanks to the 
research performed by Paul Müller at the Geigy laboratories in Switzerland (Jarman and Ballschmiter, 2012; Simon, 1999; Straumann, 2005). DDT was first used in military campaigns in Italy, against vector insects producing typhus and malaria. With the support of the Rockefeller Foundation, DDT was adopted in both public health and agriculture in many countries in Latin America and Europe in the mid-1940s (Fitzgerald, 1986; Stapleton, 1998; Palmieri, 2010). Lead arsenate had been used for similar purposes in the previous decade, but the chemical and toxicological properties of the new organochlorine chemicals opened up new possibilities as they did not appear to be dangerous to cattle, humans or crops.

Thanks to public health and military campaigns, along with its apparent absence of acute toxicity in operating doses, DDT came to represent the triumph of modern technology over pests and disease. Its positive image was projected in agronomic papers and public health leaflets and in industry advertisements, and its use was actively promoted in urban health campaigns, military barracks, schools, food stores and domestic spaces in general. The advent of DDT also fed the technocrats' dream of controlling nature (both pests and illnesses) by means of non-dangerous chemicals: so much so, in fact, that the use of other synthetic pesticides was enthusiastically embraced, and other forms of pest control systematically marginalized. The early critical voices, and the calls for caution, were silenced (Mart, 2015). The mass use of DDT in public health eclipsed all other approaches to epidemics, monopolizing the attention and reducing funding for crucial areas in tropical medicine and microbiology (Clarke, 2012).

In spite of this positive image, the new organochloride pesticides were not universally welcomed, even if the dissenting voices remained silenced for decades. Many toxicological studies of DDT carried out soon after its introduction in the 1940s offered experimental evidence of its potential danger to mammals. The dominant narrative that still persists in popular accounts and even in academic circles is that the risks of pesticides were barely known until the publication of Rachel Carson's Silent Spring in $1962 .{ }^{13}$ In fact, many years before Silent Spring, public health experts had advocated caution regarding crude insecticide-based eradication methods, stressing the complex interaction between chemicals, insects, diseases, humans and the environment. Similar criticisms were raised by entomologists and agricultural engineers, particularly when the reports of disastrous experiences in cotton fields in Latin America in the 1950s provided growing evidence of insect resistance to pesticides (Murray, 1994, pp. 3237). Not only public health and entomology researchers were sceptical about the innocuous nature of the new pesticides: other groups such as beekeepers and hunters soon realized the damage caused by pesticides to beneficial insects and wild life in general (Anderson and Atkins, 1968; Suryanarayanan and Kleinman, 2017; Frøyen, 2019). To allay these fears, large amounts were invested in public campaigns extolling the virtues of DDT as a safe chemical, suitable for use in fields, in homes or in hospitals
(Conis, 2010, 2017); even so, many farmers relied on alternative methods of pest control for decades, either due to their proven efficiency or for economic reasons (Gay, 2012; Bertomeu Sánchez, 2019a).

While bearing in mind the general trends mentioned, it goes without saying that the history of DDT varies substantially in the diverse contexts in which it was applied. Like other pesticides with both material and political dimensions, DDT was adopted in different ways according to the different social, cultural, economic and political contexts, the different protagonists involved in this process (industry, farmers, householders, agronomy and public health experts), and the agroecological and sanitary conditions (main crops, pests, and epidemics) (Riegert, 1980; Dunlap, 1981; Carter, 2008; Fernández Bravo, 2018; Bertomeu Sánchez, 2019a).

In Spain, many of these issues are still to be analysed from a historical perspective, but some preliminary features can be gathered from a study of the available literature. ${ }^{14}$ The new organochlorine pesticides were known in Spain in the early 1940 s - initially only in reduced circles, mostly experts in agriculture engineering and public health. In a document written in December 1941, Geigy industries announced that everything was in place for the exportation of "Gesarol" (their trademark for DDT) to countries such as Holland, Belgium, Portugal, Turkey and Spain (Straumann, 2005, p. 236). One of the first agriculture engineers who performed experiments with these products was Alfaro Moreno, the director of the campaigns against the Colorado beetle, who claimed that he had been dealing with the new organochlorine products since 1942. Two years later he reported his experiments and compared the new products to lead arsenate, the product he had recommended until then in the fight against the beetle pest. He affirmed that the effects were "similar" in insects, but he acknowledged that DDT seemed to be less toxic than arsenic for mammals. The main problem was its high price in comparison to previous pesticides. ${ }^{15}$

Alfaro performed a large number of laboratory and field experiments to test the great variability of the effects of pesticides. He noted the differences in the concentration of active isomers in the commercial samples. Since the summer of 1943, another agriculture engineer, Miguel Benlloch, had performed "more than a hundred" experiments with new organochloride pesticides (DDT and $\mathrm{HCH}$ ) at the Madrid Phytopathological Station, in which he affirmed that new mixtures of isomers had been developed. ${ }^{16} \mathrm{He}$ concluded that the new pesticides had very promising properties, particularly their stability and their action by contact, but warned against excessive optimism regarding their usefulness and harmlessness. He mentioned several cases in which DDT had already been shown to be inefficient against certain pests and he remarked that the spectrum of action remained unknown, and so there was a serious risk that it might damage beneficial insects. Moreover, Benlloch warned against making excessive claims regarding the lack of toxicity of DDT in mammals, stressing that many aspects of the toxicology of organochlorine pesticides were still to be established 
("todavía hay mucho que investigar"). Reviewing the available data on toxic effects on humans, he nevertheless accepted that the current experience at the doses used in agriculture suggested that they were innocuous (Benlloch, 1945a) and in May 1945 he was already recommending the use of DDT against many different agriculture pests in answer to questions addressed by farmers (Benlloch, 1945c).

Apart from their doubts about efficiency and safety, the main concern of agricultural engineers in the early years of the use of DDT was quality control and fraud. Benlloch, who was in charge of one of the main pesticide quality control laboratories, highlighted this issue as the main problem facing the expansion of the use of the new organochlorine pesticides. The available commercial products seemed to have very different insecticidal effects, and the chemical methods for controlling the quality of these complex mixtures of organic isomers were unreliable. In 1944, the director of agronomic services in Barcelona requested chemical analyses of samples of DDTbased pesticides due to their increasing use in agriculture (Quintana Marí, 1944; Quintana Marí and Cid Capella, 1946). In addition to the complex mixtures of isomers, Benlloch soon realized that the efficacy of organic pesticides depended on many other different issues: for instance, the differences in the quality of pesticide suspensions in water, which might be created without sufficient care by unskilled farmers trying to follow the guidelines provided by the industry. Other crucial pesticidal effects largely depended on issues such as the insects involved, temperature, humidity, soil, and so on which were complex, changeable, and difficult to control in laboratory experiments (Benlloch, 1945d).

The precautionary tone in the reports by Alfaro and Benlloch is also found in the first references to DDT in journals such as Agricultura, edited and written by agricultural engineers but addressed to a broad readership of landowners and farmers. The first references to DDT appeared in mid-1944, when the product was already being used in the fields. These early publications included reports on the extraordinary virtues of the new pesticides but also made calls for prudence and for further research and experimentation before the final adoption of the new products. In May 1944, a report published in Agricultu$r a$ described several new pesticides, leading the trend to replace arsenic products by less dangerous products to humans and cattle. DDT ("Gesarol") was the most important one, and was supported by "an intensive propaganda" campaign that had been launched during the previous months. The anonymous author noted that its pesticidal power was similar to arsenates but its price was "more than twice (as high)", which limited its use in high-productivity crops. The author also warned against excessively optimistic views regarding DDT as a "panacea" against all pests, because it had been shown to be inefficient for killing certain insects. ${ }^{17}$ Another paper published in the following months decried the overenthusiasm regarding the "excellent qualities" of DDT and warned against the rush to use large quantities of DDT in some areas in
Spain. The anonymous writer noted the diverse value of the commercial products, the difficulties of using chemical analysis in quality control and the potential risks to human health, even mentioning the tragedy of other pesticides such as Naaki, a finely ground quartz dust which had been introduced in the 1930s but banned when it was shown to cause silicosis in farmers. ${ }^{18}$

Along with its early uses in agriculture, DDT was adopted in public health campaigns against typhus and malaria. While malaria was a chronic disease in some parts of Spain, typhus epidemics were a consequence of the poor nutritional status of the population and low levels of hygiene in the early 1940s (Estellés Salarich, 1944; Jiménez Lucena, 1994; Rodríguez Ocaña, 2017). Experiments with DDT were performed in a number of sites affected by these epidemics. For instance, under the supervision of the medical and political authorities in Valencia, a medical commission performed several experiments with people and clothes infested by lice using DDT samples obtained in high street shops. The doctor who wrote the report concluded that DDT was not as potent as cyanide fumigations and wondered whether the commercial products in Valencia were in fact less effective than the ones used in Naples by the US army during the fumigation against the typhus epidemic in 1943 (Vidal Jordana, 1943; Vidal Jordana and Rodríguez Fornos, 1946). ${ }^{19}$

The most important work with DDT was carried out in the context of malaria campaigns, which were a major medical problem in many areas. Special commissions had been established in the preceding years and several medical measures had been implemented, along with the use of Paris green and other arsenical pesticides against Anopheles mosquitoes (Rodríguez Ocaña et al., 2003; Rodríguez Ocaña, 2005). Many doctors became interested in organochlorine pesticides after the Sardinia campaign in Italy in 1944, among them the military doctor Piédrola who published several books summarizing recent research on medical uses of DDT (Piédrola Gil, 1945, 1948a, 1948b; Piédrola Gil and Matilla Gómez, 1947). He also wrote on the fumigation of military barracks (Piédrola Gil, 1950).

While agricultural engineers and public health doctors were still studying the new products and performing field and hospital experiments, newspapers and agriculture magazines had been carrying articles on DDT since the end of the Second World War. This was also the case in other countries (Gaissler, 2015, pp. 70-75). Advertisements were published not just by the Swiss producers, but also by a wide range of Spanish companies, from pharmaceutical and chemical industries to small producers and retailers who were interested in the profits accruing from the demand for the new pesticides in agriculture, public health and the home. Thus, the new organochlorine pesticides produced a sudden and unexpected change in the Spanish pesticide industry, which had been created in the early 1940s to produce and exploit arsenical compounds with the support of the policies of autarky and the pest control programmes developed by agriculture engineers. 


\section{CHANGES IN THE EARLY PESTICIDE INDUS- TRY}

So the arrival of DDT in Spain practically coincided with the mass introduction of arsenical pesticides against the Colorado beetle pest and the establishment of an incipient Spanish pesticide industry based on these products, using national mineral resources and supported by the politics of autarky. The increasing demand for pesticides, along with the crisis in imported products during the early 1940s, produced a black market of adulterated products which raised alarm among agriculture engineers. In 1940, just a few months after the end of the Civil War, agricultural engineers managed to set up a permanent programme for the "inspection of the production and commerce of insecticides". ${ }^{20}$ Two years later, the National Register for Phytosanitary Products was created, shortly before the establishment of a similar service in Vichy France. The priorities of the Spanish National Register, like those of its French counterpart, were the promotion of intensive agricultural production and the development of the pesticide industry, rather than any public health concerns. ${ }^{21}$ The register aimed to encourage national production (a separate procedure was created for imported pesticides, with stricter requirements) as well as to prevent the trading of faulty products and adulterations. In fact, most of the applications for trading pesticides submitted during the first months of 1943 were made by local industries, most of them producing arsenic pesticides. ${ }^{22}$

The register was created at the end of 1942, almost at the same time as the first news of the pesticidal virtues of DDT arrived in Spain. During the next year, the first imported samples of Gesarol soon sold out and its price skyrocketed. The producers of arsenic pesticides, whose local production had been substantially increased for the reasons mentioned, took fright; with the help of the new regulations, they managed to delay the importation of new organochloride compounds. ${ }^{23}$ By the early 1950 s, around a thousand pesticides produced by Spanish industry had been submitted, but only a hundred from abroad. ${ }^{24}$ The applications frequently highlighted that they were comprised only "national products". Foreign industries were included in a separate register with stricter requirements. Samples of the pesticides, along with description of the manufacturer, were sent to the Provincial Agriculture Offices, whose directors wrote a preliminary report (focusing in particular on the activities of the producers and their capacity for making large amounts of pesticides). The product was sent for analysis to the laboratory run by Miguel Benlloch, head of the Madrid Phytopathological Station. He reported the effects of the pesticide, the existence of similar products (thus avoiding resale) and the absence of damaging effects for the plants. More than 900 products were analysed by Benlloch between 1943 and $1950 .{ }^{25}$ Many of the proposals were rejected: more than a quarter were turned down during the first decade. Around six hundred pesticides were admitted by the end of 1952 , while a hundred more (most of them foreign products) were "provisionally accepted", ${ }^{26}$
As stated above, during the early years most of the registered pesticides were arsenical insecticides such as lead and calcium arsenate. In 1943, thanks to increasing demand, the difficulty in importing products, and the high market prices of the pesticides, a large number of local industries attempted to produce DDT and similar organochlorine products. According to an anonymous professor of chemistry, around 30 chemists were working in different laboratories in the synthesis of DDT and, by the end of 1944, at least "six Spanish industries" had succeeded in producing it. Within a few months, there were eleven firms manufacturing DDT in Spain. But the laboratories' desire for a rapid return on their investment meant that the quality of the product suffered. The career of many of the local firms as DDT producers was short-lived: they never had the laboratory resources or the manpower required to make high quality organic pesticides. ${ }^{27}$

The impact of DDT in the emerging Spanish pesticide industry can also be traced in the register of pesticides. The first group of authorized products (around 60) were almost all arsenical compounds (Paris green, sodium, calcium or lead arsenate, among others). In the register, the first organochlorine pesticide authorized was "ZZ", a product made by an up-and-coming pharmaceutical company, Zeltia, which was also one of the first companies to advertise DDT in journals such as Agricultura. ${ }^{28}$ Another pioneering producer was another pharmaceutical industry, the Fábrica Española de Productos Químicos y Farmacéuticos in Bilbao, which produced "Detano", a mixture presented as the "true and real DDT", obtained following the firm's own method..$^{29}$ Other important industries producing DDT in the mid-1940s were Sociedad Anónima Cros, a producer of fertilizers and connected in earlier years to the German firm IG Farben; Fabricación de Colorantes y Explosivos, a chemical industry in Barcelona which also commercialized several organochlorine pesticides under the trademark "Inu Agrícola"30; and Cruz Verde, a firm also based in Barcelona area which manufactured and sold a broad range of pesticides for agricultural and domestic uses. ${ }^{31}$ Other early producers of DDT were small local firms such as José Escorihuela Perelló, Francisco Villanova Ibañez, and José Ramón Rivelles Talón, most probably small retailers of agrochemicals in the Valencia area. ${ }^{32}$

The number of foreign industries was small, for the reasons mentioned above. An exception was Geigy industries, the first producer of DDT, which managed to establish a branch office named Irga in Barcelona and obtained the first authorization to sell "Gesarol", the DDT mixture designed for agriculture. It was followed by products created for other uses such as controlling parasites in cattle and killing insects. Many advertisements for these products were published from mid-1945 onwards in local and national newspapers and in farming journals. ${ }^{33}$

After 1945, an increasing number of organochlorine products were registered, around two thirds of them made of different mixtures of DDT. Other important products were hexachlorocyclohexane $(\mathrm{HCH})$ and its gamma-isomer (lindane) ${ }^{34}$ By the end of 1952 organochlorine com- 
pounds had established themselves as the most important group, accounting for around a third of all insecticides and almost doubling the number of arsenate compounds. The other important group of insecticides were mineral oils and products of plant origin, mostly from nicotine. Apart from insecticides, the other important group in the register were the fungicides made of copper salts (Bordeaux mixture) or sulphur. ${ }^{35}$

Arsenical pesticides were progressively replaced by DDT, but they continued to be used in the fields for many years. At the end of the 1950s, for example, in a popular radio magazine addressed to farmers, the two pesticides recommended by agricultural engineers against the Colorado beetle were lead arsenate and DDT mixtures (Radio Agrícola, 1959). Apart from arsenates, DDT pesticides co-existed and competed with other new organic pesticides which were introduced in the mid-1940s. One of most important in agriculture and public health was $\mathrm{HCH}$ (or "666"), which was heralded as a Spanish discovery and attributed to Juan Gomeza, a pharmaceutical chemist working at Insecticidas Cóndor SA, one of the main producers of pesticides in the 1940s. In fact, the molecule had been synthesized in the early nineteenth century and its pesticidal virtues had been discovered in laboratories in UK and France during the early 1940s. ${ }^{36}$

Juan Gomeza knew of these developments but he claimed that the discovery was "exclusively due to Spanish research, whose chemists are beginning to revolutionize the national industry, with total independence of the work [in other countries]". According to his account, after the synthesis of the new product, experiments were carried out at the Madrid Phytopathological Station by Miguel Benlloch; Álvaro Lozano Morales studied its applications in malaria control, Gonzalo Piédrola in military hygiene, and the entomologist Gil Collado studied its potential uses in disinfestation of cattle (Gomeza Ozámiz, 1945; Lozano Morales, 1945; Fernández Astasio, 2003, pp. 365366; Rodríguez Ocaña et al., 2003, pp. 294-295; Andrés Turrión, 2019, pp. 187-188). The new product was soon authorized and included in the pesticide register, just after the first DDT products. It was registered under the trademark "Gelón" and was proudly presented in many publications as the "insecticida español 666" (Moreno Martín, 1946). Priority claims were made during the following years; the developments in the UK and France were reviewed and the terminology was discussed (Piédrola Gil, 1953a, 1953b). In the following years, a particular isomer of this compound, gamma-HCH or lindane, became one of the most popular Spanish pesticides, and a flourishing industry was established in Galicia, the Basque Country and northern Aragón. Lindane was to become notorious at the end of the twentieth century, due to the health risks and the environmental problems it caused (Vijgen et al., 2006; Barberá Pertusa, 2018; Pérez, 2019).

\section{NEW DISCOURSES ON PESTICIDES}

The arrival of the new pesticides led to changes not only in the chemical industry, but also in the way pesticides were represented in public. In the earlier years, with the development of the new arsenical pesticides, agricultural engineers used three main themes in their campaigns. First, they applied their common rhetoric of costs and benefits to other aspects of crop yields. By performing controlled field experiments or gathering data from their campaigns, they provided quantitative data showing the differences between the economic damage caused by insects and the price of pesticides. The economic balance was presented as convincing evidence of the advantages of investing in pesticides and equipment. Of course, these calculations did not take into account collateral costs such as farmworkers' diseases, public health risks and environmental problems (Pimentel and Lehman, 1993, pp. 47-84; Murray, 1994). Other common topoi were military metaphors: pest control campaigns and human wars were presented in similar terms, with references to invasions, contention, troops, weapons, annihilation, and so on. This language was in fact an expression of deeper connections between warfare and the pesticide industry regarding its products, technologies, expert communities and potential markets (Russell, 2001). In the early years of the Franco regime, Spanish politicians commonly spoke about the war against the communist plague, while agriculture engineers appealed to nationalist sentiment and dreams of modernity in order to support the use of pesticides; reluctant farmers were portrayed as selfish and unpatriotic individuals whose backward and inefficient methods had no place in the renewed Spanish state. Finally, the rhetoric of autarky stressed the connections between the arsenic mines in northern Spain and the emerging pesticide industry, so many advertisements highlighted that the products were made with Spanish natural resources (Bertomeu Sánchez, 2020).

With the arrival of new pesticides, some of these themes continued to be used and at the same time new images gained momentum. Following the trend of previous years, military metaphors were frequently found in advertisements for pesticides, and descriptions of pest control activities were also used to express political messages. In the advertisement published by Agumar retailers, pesticides such as arsenates, Bordeaux mixtures and DDT were depicted as motorized troops moving along a road on the way to wage war against pests in different villages. ${ }^{37}$ And in an article published just after the award of the Nobel Prize to Paul Müller, the journalist offered a critical review of US international policy against communism under the title of "Truman's political DDT":

\footnotetext{
Mr Truman believes, with the votes of the 23 million Americans who renewed his presidential mandate behind him, that the best anti-communist DDT is democracy. In the coming months, a powerful diplomatic and economic initiative is to be expected from Washington to spread this magic formula. Just now, Dr Paul Müller from Basel has received the Nobel Prize for his chemical DDT. We hope that Mr Truman will soon be awarded a Nobel Peace Prize for his political DDT. It's a difficult adventure, and we disillusioned Europeans are rather sceptical. But he's going to try. ${ }^{38}$
} 
The sociomaterial features of the new organochlorine pesticides provided rhetorical resources for new discourses and imaginaries depicting their virtues and risks. In the beginning, the different uses of DDT in agriculture, public health and domestic contexts encouraged the emergence of specific trademarks created by the companies and campaigns addressed at the target customers. For instance, Geigy created "Gesarol" (agriculture), "Neocid" (anti-parasites), "Neocidol" (for the disinfection of cattle) and "CAM" for domestic use. In each case, gendered images were used: women were depicted cleaning homes with "CAM" insecticides, while male farmers and scientists appeared in the adverts for the other products. ${ }^{39}$ Other industries followed similar commercial strategies. Cruz Verde produced not only insecticides but also soap and colognes with DDT, and their adverts were also addressed to "mothers" who were "eager [to protect] the cleanliness and health of their children". ${ }^{40}$

Moreover, the uses of DDT during the Second World War introduced new possibilities for associating the war on pests in agriculture with action against annoying insects in the home and with large-scale public health campaigns for the eradication of typhus and malaria. The new products were presented as sources of economic profit, health and comfort to humankind (Vail, 2012). Geigy industries published many adverts for their different products while noting that "Swiss chemists had discovered the DDT insecticide, adopted by armies and by health and agricultural authorities all over the world" ${ }^{41}$ Arsenic products had also been used in the past against Anopheles mosquitoes and for the disinfection of cattle, but their high toxicity ruled out their use for humans in public health and domestic contexts. One of the main ideas repeated in the advertisements in the mid-1940s was the innocuous nature of the new organochlorine compounds such as DDT. Many advertisements insisted on this point in 1945-in stark contrast to the prudence expressed by agricultural engineers in their first reports discussed in previous sections. The tensions can be perceived in the following example. When Benjamin García Milà of "Cruz Verde" submitted the application for registering its DDT pesticide in mid-September 1945, he included examples of leaflets and advertisements declaring, in large letters “ ¡No es venenoso!” (It isn't poisonous!). One of them was addressed to farmers:

Farmers, to combat the potato beetle, the beet flea and the alfalfa worm, use Cruz Verde Agricultural InsecticideDichloro Diphenyl Tricoloroethane. You'll increase your yield and protect your family too. Good for you and good for your livestock. Because Cruz Verde is not poisonousit doesn't contain arsenic. ${ }^{42}$

In his positive report, Miguel Benlloch recommended the rapid registration of the product but he asked for the claims regarding the safety of DDT to be qualified and for more accurate information about its virtues. He suggested reformulations, such as "it is not poisonous at the recommended doses" or "harmless at the applied doses." ${ }^{43}$ Other problems of DDT (such as insect resistance, damage to beneficial insects or toxicity to mammals) were discussed very early on by doctors and agriculture engineers. ${ }^{44}$ Agrochemical advertising for DDT and $\mathrm{HCH}$ (not just the campaigns launched by Cruz Verde), continued to use adjectives such as "efficient", "productive", "innocuous", and "non-poisonous" in their slogans. Another particular feature of DDT highlighted in the advertisements was its lack of taste, which meant that it did not alter the flavour of the produce. This had been a major problem for $\mathrm{HCH}$ before the isolation of lindane, its gamma isomer. ${ }^{45}$

Another common trope in the advertisements was the progress achieved by science in both agriculture and public health. The new organochlorine products were presented as the result of scientific research, and images of laboratories, instruments and scientists featured frequently in the adverts. No such images had been found in advertisements for earlier products such as arsenical pesticides or the popular Bordeaux mixture which focused on farmers, plants or insects and included texts asking for rapid action against the pest. In contrast, DDT was presented as the result of scientific progress; the advertisements sometimes included specialist terminology (such as "isomers") or academic-like reports. ${ }^{46}$

An important concern was the quality of the DDT mixtures, an issue raised both by agricultural engineers and by political authorities. Due to their domestic and medical properties, organochloride pesticides were included in the register of pharmaceutical drugs, so their quality was monitored by the pharmaceutical inspectors and they were on sale in pharmacies. However, the main concern was the control of quality in terms of efficiency. ${ }^{47}$ Many advertisements referred to this issue by rejecting "fake" or "adulterated" products and presenting the "real" and "effective" DDT mixture, which was obtained in the company's laboratories. Geigy in particular used this approach, presenting its products as the "real" DDT created by its discoverers; ${ }^{48}$ the firm published short accounts of the discovery at the "laboratories J. R. Geigy", suggesting that their products were the "original and legitimate DDT". ${ }^{49}$ In other cases, DDT was presented as "the triumph of modern Swiss chemistry", the result of "more than ten years" of research made by "a team of 65 researchers" at Geigy, thus "yielding a great service to humankind". ${ }^{50}$ Geigy industries and their collaborators in Spain such as Irga and Laboratorios Padró in Barcelona also celebrated the Nobel Prize awarded in 1948 to Paul Müller, who was described as "director of the Geigy research laboratories". ${ }^{1}$

Countering these claims, Spanish firms also presented their products as the results of their own scientific research, and to this end registered their own trademarks such as "ZZ" and "Detano". In press reports they stated that many organochlorine compounds (including DDT) had been synthesized in the nineteenth century, thus stressing the idea that "current science is based on past research", that is to say, organochloride pesticides were far from being an isolated and exceptional discovery in a remote Swiss laboratory, but the result of collective sci- 
entific progress. Expanding on this idea, FAES published several advertisements depicting a chemical textbook with instruments and chemical formulae, with the slogan "Chemistry is an open book within the reach of everyone". They presented their own product ("Detano") as the "true and real" DDT, obtained and patented by themselves. ${ }^{52}$ The different DDT products were advertised as the result of research in Spanish laboratories. In March 1945, Zeltia announced that "Spain would soon benefit from a dramatic wartime discovery" without "waiting for peace". "All the modernity and efficacy of DDT" would be "scientifically" captured in a new insecticide produced in Spain ("de elaboración nacional") and sold under the tradename "ZZ". Zeltia claimed to be producing the new insecticide in more intensive ways in order to cover the national demand in agriculture and public health. ${ }^{53}$

Presenting organochlorines as homegrown products in pesticide advertisements was a way to mobilize patriotic feelings and national pride, so characteristic of Francoist politics. Slightly earlier, in tune with the autarky discourse of the 1940s, it had been arsenic pesticides that were proudly presented as products of exclusively "national resources". Now, with the advent of the new organochlorine pesticides, advertisements and the agronomic literature spoke of "national research" rather than of "national resources". $\mathrm{HCH}$, for example, was praised as a Spanish discovery developed at Zeltia's laboratories, not just in advertisements but in chemical and agricultural journals. ${ }^{54}$ When Cruz Verde managed to produce lindane (an isomer of $\mathrm{HCH}$ ), the firm also hailed it as "a new achievement of Spanish industry". 55

Moving away from the rhetoric of autarky, and reinterpreting patriotism in scientific terms, the new organochlorine pesticides were also presented in connection with the Franco regime's national and international policies in the mid-1940s. Some industries enlisted the support of rural organizations ("Hermandades de labradores") in order to advertise their products, which were also distributed with the help of the Francoist unions and the agricultural engineers. For instance, included in their advertisements Cruz Verde letters signed by the president of the Hermandades de Labradores confirming the efficacy of DDT in pest control: the letter finished with the standard Falangist motto "Por Dios, España y su Revolución Nacionalsindicalista (For God, Spain, and the National syndicalist revolution)". ${ }^{56}$

DDT arrived just as the newspapers were reporting the final victory of the Allied armies over the Fascist governments of Germany and Italy, two of Franco's most important international allies during the Civil War and the early 1940s. In fact, the mid-1940s were bleak years for the emerging authoritarian regime due to its international isolation after the Second World War. In 1946, the General Assembly of United Nations excluded the Franco government from international organizations and conferences. The regime adopted several measures to overcome these obstacles with propaganda campaigns and new movements in international policy. Presented as one of the tools in the victory of Allied armies, DDT was a good resource for implementing new discourses that praised the modern technologies of the US. Reports published in the press in 1945 highlighted the role of DDT in the victory of the Allied armies, for instance, in the fight against terrible locust swarms in north Africa or in the campaign against typhus in Naples. ${ }^{57}$ Several articles were published on the Peronist government in Argentina, which was helping the Spanish government against international isolation, and was pioneering aerial DDT fumigations with the help of US technologies. ${ }^{58}$ After the Japanese capitulation, newspapers reported DDT fumigations carried out by the US army against "germ-bearing insects". 59

Summing up, talking about DDT in the mid-1940s in Spain presented an opportunity to praise the achievements of the international allies of the new regime and to move away from the embarrassing connections to the Fascist regimes, which had been defeated thanks in part to the scientific achievements during the war: penicillin, radar, the atom bomb and DDT. ${ }^{60}$ The new organochlorine mixtures were presented as efficient and harmless to plants - and, unlike arsenates, as safe and non-poisonous to humans and livestock. After 1945, agrochemical advertising flooded not just newspapers but agriculture magazines as well, where it appeared alongside agronomic reports and guidelines and recommendations offered by agriculture engineers. Thanks to the increasing demand, organochlorine pesticides offered new connections between scientific research and patriotic feeling, in tune with the programmes for pest control developed by agriculture engineers and the new policies promoted by the Francoist regime after 1945.

\section{CONCLUSIONS}

The above discussion sheds new light on the emergence of the Spanish pesticide industry during the first decade of the Franco regime. The process was complex and affected by many factors, including the old and new sociomaterial products used in pest control, a broad range of human and non-human protagonists, and changing economic policies and discursive practices. At the start of the period, the early 1940s, the large-scale use of arsenical pesticides was aimed at fighting the spread of a new pest, the Colorado beetle, and encouraged the development of Spain's agrochemical industries in the context of the autarky policies of Franco's early governments. The shortage of agrochemicals due to the wartime crisis, the restrictions on international trading, and the discovery of arsenic ores in northern Spain were additional issues that shaped the early years of the Spanish pesticide industry. Moreover, agricultural engineers supported the mass use of pesticides as the sole form of pest control in those years. This reductionist, simplistic approach to pest management and disease control was in tune with the regime's policy on self-sufficiency regarding the use of natural resources and the interests of the emerging agrochemical industry. Moreover, pest control campaigns also served in to the surveillance of rural areas and the making of a centralized economy, which formed the basis of the authoritarian, Fascistoid regime in its initial stages. 
Thus, regarding pest control at least, the first years of the Franco regime can hardly be portrayed as a "technological blackout". On the contrary, substantial technological innovations were introduced as the new authoritarian state sought to establish itself in the early 1940s. In spite of the oppressive political atmosphere, the mass introduction of arsenical pesticides faced resistance from farmers, hunters and other silenced voices, which were answered by multimedia campaigns sponsored by industry and agricultural engineers along with acts of political repression. In the discursive realm, images of economic profit achieved by means of pesticides and military metaphors in the fight against pests were intermingled with patriotic feeling and depictions of the Fascist-like modernity promoted by the Franco regime.

The arrival of the new organochlorine products substantially changed this scenario in mid-1940s, just when the regime found itself facing international isolation and obliged to reconsider its domestic and international policies. Without entirely replacing previous pesticides, the new products started to be used in agriculture, public health and homes. At the same time, agricultural engineers and doctors studied their efficiency and toxicity and attempted to control their quality by means of chemical tests. Without waiting for the results of the research, a broad range of producers and retailers started to sell the new products in 1945, in spite of the calls for prudence from experts. In contrast with arsenical pesticides, the new products did not depend on the natural resources available; they could be synthesized in laboratories. These sociomaterial features of organochlorine pesticides opened up a new spectrum of uses and created new discursive practices. DDT and other similar products were marketed in a way that praised their safety and health benefits, but also appealed to the patriotic pride of the potential buyers. Spanish firms, the campaign went, were at the forefront of scientific progress, discovering new products and successfully synthesizing the new pesticides in their industrial laboratories. The new organochlorine pesticides also provided a rhetorical device for establishing connections with the regime's new international allies such as Argentina and the US.

The changes in the mid-1940s also affected the groups involved in the production and distribution of organochlorine pesticides. New problems of quality control, fraud and adulteration emerged and encouraged new research on chemical tests. Quality control was the main focus of the new regulations published in the 1940s, which largely overlooked the problems of public health, occupational diseases, and ecological damage caused by the pesticides, even though these problems had already been pointed by agriculture engineers and doctors. The toxic risks of pesticides were concealed, and responsibility for their effects was passed onto the farmworkers and rural communities; consideration of the longer-term impact on food consumers and ecological systems was ignored. The greatest profits were obtained by the big landowners, who obtained increased crop yields, at least in the first years; by the agrochemical industries, which reaped the benefits of an expanding market for their products, and not only in agriculture; and by the Francoist government, which was presented with a set of economic and discursive practices that were in tune with its domestic and international policies and also represented a useful way of controlling rural areas. This imbalance also encouraged undone science (the marginalization of other existing methods for pest control) and agnotology (the silencing of critical voices through discursive and repressive measures along with the flood of propaganda and advertising). With the help of the agricultural engineers, this unequal distribution of risks and benefits became the norm in the 1940s and shaped the further development of the Spanish pesticide treadmill during the decades to come. We have shown that the arrival of new pesticides such as DDT and $\mathrm{HCH}$ was moulded by this multifaceted context, which in turn was substantially changed by the sociomaterial features of the new products.

\section{ACKNOWLEDGEMENTS}

The research was supported by the programme HAR2015-66364-C2-2-P. A New Scholar Award was granted by the Society for the History of Alchemy and Chemistry to Silvia Pérez Criado for archival research. We are also very grateful to the staff of the AGA archives (Alcalá), the Instituto de Investigaciones Agrarias library (Madrid) and the Vicent Peset-Llorca library (Valencia) for providing access to the documents and books consulted. We are also indebted to Michael Maudsley for his careful revision of the English.

\section{NOTES}

1 See Bertomeu Sánchez (2019a)

2 The master narrative including these ingredients is Simpson (1997). On the use of pesticides in Spain at the beginning of the twenty-first century, see the data provided by Eurostat in https://ec.europa.eu/eurostat/web/products-eurostat-news/-/ DDN-20181015-1 (accessed 12, 28, 2018).

3 See Pujol (2001).

4 On Fascism and agriculture see Fernández Prieto, Pan-Montojo and Cabo, 2014, pp. 19-43. In tune with this work and Saz (2004), we used the term "Fascistized regime" to refer to the Fascist ingredients in the early Francoist policies as well as to the process of Fascistization of right groups and traditional elites. Needless to say, the difficulty of defining "Fascism" is one of the most common issues in both contemporary accounts (e.g., Ortega y Gasset's famous texts) and historical scholarship such as the classic books by Griffin (1993) and Paxton (2005). See also Costa Pinto (2012).

5 Some examples of this blossoming literature on science and technology in the Francoist regime are Camprubí (2017); Gorostiza (2017); Néstor and Roqué (2013); Nieto-Galan (2019); Swyngedouw (2015). See also papers included in this volume.

6 The issue has been recently discussed by Martín Albaladejo and Sanchiz (2017). The authors adopted an approach very different from the one adopted here. We particularly disagree with the claim that "entomology, as it was practiced at the time, was a zoological discipline engaged in taxonomic and faunistic research, with no industrial or economic relevance" (p. 336).

7 For examples of the complex relationships between modernism and Fascism, see Griffin (2007), Bonneuil and Thomas (2010) and Fernández-Prieto, Pan-Montojo and Cabo (2014). On other 
"Francoist engineers" see Camprubí (2017) and Swyngedouw (2015).

8 The relevance of Colorado beetles in the emergence of British pest control services is also remarked by Clark, (2009). See also Cook, (1998); Whorton, (1974).

9 See reports on pest control in different areas of Spain in the series Agricultura (61), Archivo General de la Administración (hereafter cited as AGA). See Alfaro Moreno, (1945).

10 "Orden de 11 de mayo de 1944 sobre medios de defensa contra la plaga del escarabajo de la patata", BOE, 15 May, 1944, 38922803. See also Agricultura, 1944, 13 (145): 340-435.

11 Hoja Oficial del Lunes, 18 June 1945. See another example in Diario de Burgos, 21 July 1944.

12 Diario de Burgos, 18 May 1944, 1. Order signed in Burgos, 17 May 1944 by Manuel Yllera García-Lago, a leading Francoist politician who organized a campaign of violent repression against the political opposition in Burgos. On his role in censorship, propaganda and newspapers see Sanz (2016).

13 See, for example, Andrés Turrión (2019, pp. 183-184): “No había - ni en España, ni en el resto del mundo- debate público sobre sus efectos adversos. Solo a lo largo de la década de 1960, tras la publicación en 1962 de la obra Silent Spring de Rachel Carson, se inició un largo y lento proceso de concienciación pública y debate conservacionista". For a review of new studies on Carson see Pérez (2017).

14 Reliable statistical sources on production and usage are lacking, but some numbers and trends are offered in González de Molina, Soto and Guzmán (2020, pp. 94-97). We are grateful to prof. Ignacio Suay-Matallana for information on this recent publication.

15 "[DDT] tiene una acción comparable apara los adultos, da en el agua suspensiones acuosas de gran estabilidad que permiten hacer pulverizaciones uniformes, y no parece tóxico para los animales de sangre caliente a las concentraciones corriente empleadas en el tratamiento de las plantas. Su precio de coste resulta algo alto, y lo limitado del tiempo en que se viene usando no nos ha permitido comprobar si, como se asegura, sus condiciones insecticidas permanecen inalterables al envejecer el producto". Cf. (Alfaro Moreno, 1944, pp. 35-36).

16 Benlloch presented his results at the first International Conference on Phytopharmacy, which took place in Heverlee-Louvain (Belgium) in September 1946. See Benlloch (1945a).

17 Informaciones (1944) “... Nuevos insecticidas”. Agricultura 13, 375-376.

18 Informaciones (1945) “... El nuevo insecticida D.D.T y sus similares", Agricultura 14, 82.

19 We are grateful to Prof. Àlvar Martínez-Vidal for providing us with these valuable data.

20 BOE, 4 September 1940, (Order 13 August 1940). See Agricultura 9 n. 96 (1940, pp. 137-139).

21 Jas, "Public Health and Pesticide Regulation" pp. 375-377.

22 "Decreto de 19 de septiembre de 1942 sobre fabricación y comercio de insecticidas, anticriptogamicidas y material de aplicación", BOE, 23 October 1942, 8479-78. For previous attempts see also BOE, 9 April 1941.

23 Confidencias... (1947), p. 164.

24 Dirección General de Agricultura, 1953, includes data until the end of 1952.

25 Benlloch (1951).

26 Dirección General de Agricultura, 1953, pp. 4-5.

27 Confidencias... (1947).

28 Anuncio - ZZ Producto de la serie D.D. T. (Insecticida Zeltia), 1945. Agricultura 14, p. 259. See Pesticide Register numbers $81,82,83,84,85,222,223,376$ and 380 . Many advertisements were published in Agricultura after May 1945.

29 ABC, 3 June 1945 , p. 36

30 See Pesticide Register n. 100-101. Advertisements in Agricultura, 15 (176): 658, December 1946 and in the general press as "Unicolor S.A.": Diario de Burgos 23 April 1946; Imperio, Diario de Zamora de Falange Española de las J.O.N.S, 2 May 1948; etc.

31 See Pesticide Register n. 320. Many advertisements were pub- lished in Agricultura after the beginning of 1946 and in the general press: for instance, Nueva Alcarria, 9 March 1946, Diario de Burgos 22 March 1947, etc.

32 See Pesticide Register numbers 109, 136, 179, 180 and 306 for José Escorihuela Perelló; 111, 134, 168, 245 and 317 for Francisco Villanova Ibañez; and 113 for José Ramón Rivelles Talón.

33 See Pesticide Register, n. 107. Advertisements for Gesarol were published in Agricultura after September 1945 and also in the general press, including full page images and texts in national newspapers (ABC, 12 May 1945, ABC, 10 June 1945, ABC, 11 June 1946, etc.) or the local press (El Adelanto: Diario político de Salamanca, 21 August 1945; Diario de Burgos, 6 December 1945, etc.).

34 "Números de registro que corresponden a los productos fitosanitarios españoles", Madrid 24 Dec 1949. Published in BOE, 17 Jan 1949.

35 See Pesticide Register numbers 120, 121, 122, 123, 124, 125, $126,127,131,134,136,137,138,139,140$ and 327 for nicotine pesticides; 45, 173, 181, 186, 187, 188, 189, 191, 197, 206, 285, $344,348,408$ and 418 for copper salt pesticides and 185, 189 , 195, 199, 201, 272, 276, 279, 282, 283, 288, 294, 295, 341, 403, $406,407,411,412,413,415,416$ and 417 for sulfur pesticides.

36 See Straumann (2005, p. 272). In France the research was developed by the chemist André Dupire. We are grateful to Prof. Sabine Clark for the information on Imperial Chemical Industries and their research on $\mathrm{HCH}$, a discovery which was presented in public by Dr. Roland Slade in March 1945. Relying on Oleza's account, Andrés Turrión (2019) reviews the research developed by Insecticidas Cóndor, while adopting the narrative of the "discovery" made by Oleza's team and the Spanish government.

37 'Agumar. Drogas y Productos Agropecuarios'. Agricultura 19, no. 214 (1950, p. 89).

38 Lucientes, Francisco. 'El D.D.T. Político de Truman', La Vanguardia, 7 October 1948.

39 See El Adelanto, 28 May 1946 "Líbrese señora de bichos y moscas con CAM". Or Diario de Burgos, 30 May 1936. "Una limpieza perfecta exige CAM". And compare with Diario de Burgos, 6 July 1946, "iAgricultor! No arriesgues tus cosechas".

40 ABC, 1 July 1947, p. 32. "iPrevéngase! Una madre celosa de la limpieza y salud de sus hijos no olvida la fricción diaria de agua de colonia Cruz Verde". The new DDT cologne and soap was supposed to offer protection against lice caused by contact with pets and people in schools, stadiums, buses, etc.

41 ABC, Madrid, 12 May 1945.

42 AGA, 61/6422, n. 472. V. also Agricultura 15, no. 170 (1946): 334 and Nueva Alcarria, 9 March 1946.

43 AGA, 61/6422, n. 472. Report by Miguel Benlloch, 26 October 1945, "En cuanto a la afirmación de que este insecticida como otros similares no son venenosos, que viene admitiéndose en la propaganda comercial, entendemos debería tenderse a irla sustituyendo por otras como la de "no es venenoso a las dosis aconsejadas" o "inofensivo a las dosis aplicadas" que se ajusta más a la realidad.".

44 See Salvá Miquel (1947) and Benlloch (1954). On early concerns on DDT in USA see Dunlap (1981, pp. 63-75); Mart (2015, pp. 31-66).

45 'Anuncio - Cruz Verde (DDT). Escarabajo de La Patata'. Agricultura 18, no. 204 (1949): 167. On lindane, see Pérez, (2019).

46 Diario de Burgos, 22 March 1947 (Cruz Verde); ABC, 12 May 1945 (Gesarol-Geigy); El Adelanto, Diario político de Salamanca, 21 August 1945 (Neocid-Geigy), etc.

47 B.O.E. 134, 14 May 1947, pp. 2820 : "Orden de 8 de mayo 1947 por la que se dispone el registro en la inspección General de Farmacia de insecticidas D.D.T. y productos similares".

48 ABC, 12 May 1945; Nueva Alcarria, 10 May 1947; etc.

49 La Vanguardia, 11 May 1946, p. 16.

50 La Vanguardia, 20 July 1946, p. 10.

51 Imperio, Diario de Zamora de Falange Española de las J.O.N.S, 16 November 1948 , p. 2.

52 ABC, 3 June 1945. FAES, Bilbao: "la química es un libro abierto al alcance de todo el mundo".

53 Diario de Burgos, 14 March 1945. For modernism and Fascism, 
see the discussion by Griffin (2007). On modernization and agriculture in Fascist regimes, see Bonneuil and Thomas (2010) and Fernández-Prieto, Pan-Montojo and Cabo (2014).

54 See Pérez (2019) and supra.

55 La Vanguardia, 17 July 1953

56 'Anuncio - DDT (Cruz Verde)'. Agricultura 19, no. 214 (1950, p. 90).

57 La Vanguardia 6 February 1945, pp. 4. See also Neocid (Geigy) advertisement in La Vanguardia, 22 June 1946, pp.18 and ABC, 19 May 1946, p. 8.

58 Diario de Burgos, 6 November 1946, pp. 3-4. On Perón and DDT see (Carter, 2008)

59 Diario de Burgos, 15 August 1946, p. 3.

60 Hoja Oficial del Lunes, 29 October 1945, p. 3.

\section{REFERENCES}

Alfaro Moreno, A. (1944) La lucha química contra el escarabajo de la patata en España. Madrid: Dirección General de Agricultura.

Alfaro Moreno, A. (1945) Una calamidad pública: la plaga del escarabajo de la patata. Almería: Jefatura agronómica.

Anderson, L. D. and Atkins, E. L. (1968) "Pesticide Usage in Relation to Beekeeping." Annual Review of Entomology 13, pp. 213-238.

Andrés Turrión, M. L. de (2019) "La compañía Insecticidas Cóndor S.A. y el desarrollo del hexa-cloro benceno en la posguerra española”. In: A. González Bueno and A. Baratas, eds., Ciencia útil. Investigación básica y aplicada en Farmacia y Ciencias de la Vida durante el Franquismo. Madrid: Ediciones Complutense.

Bajo Mateos, F. (1946) El Servicio de Defensa Sanitaria del cultivo de la patata y la plaga del escarabajo americano. Madrid: Dirección General de Agricultura.

Barberá Pertusa, B. (2018) Lindano: historia y divulgación de riesgos tóxicos. Valencia: Universitat de València, Treball fi de grau.

Benlloch, M. (1945a) "Los nuevos insecticidas orgánicos". Agricultura 14 , pp. 511-516.

Benlloch, M. (1945b) "Ensayos de laboratorio sobre la acción por contacto de los insecticidas orgánicos clorados (DDT y 666)". Boletín de Patología Vegetal y Entomología Agrícola 14, pp. 189-198.

Benlloch, M. (1945c) "Consultas - Cereales atacados por un escarabajo". Agricultura 14, p. 272.

Benlloch, M. (1945d) "Observaciones sobre la eficacia insecticida de los preparados a base de DDT y gama-hexano". Boletín de Patología Vegetal y Entomología Agrícola 14, pp. 343-352.

Benlloch, M. (1951) "El servicio de comprobación y registro de productos fitoterapéuticos". Boletín de Patología Vegetal y Entomología Agrícola 18, p. 123-129.

Benlloch, M. (1954) "Punto de vista del agrónomo respecto a la prevención de los riesgos relacionados con el empleo de productos tóxicos en agricultura”. Boletín de Patolología Vegetal y Entomología Agrícola 22, pp. 181-191.

Bertomeu Sánchez, J. R. (2019a) "Pesticides, Past and Present. A review of current literature". HoST - Journal of History of Science and Technology 13, pp. 1-27. doi: https://doi. org/10.13140/2.1.4607.5528

Bertomeu Sánchez, J. R. (2019b) "Arsenical Pesticides in Early Francoist Spain: Fascism, Autarky, Agricultural Engineers and the Invisibility of Toxic Risks". HoST - Journal of History of Science and Technology 13, pp. 53-82. doi: https://doi. org/10.2478/host-2019-0004

Bertomeu Sánchez, J. R. (2020) "El escarabajo del marqués: Organismos sociotecnológicos, violencia lenta, plaguicidas arsenicales y cine agrario durante los primeros años del franquismo". In:
X. Guillem Llobat and A. Nieto Galan, eds., Tóxicos Invisibles. La construcción de la ignorancia ambiental. Barcelona: Icaria, pp. 79-108.

Bonneuil, C. and Thomas, F. (2010) "Purifying Landscapes: The Vichy Regime and The Genetic Modernization of France". Historical Studies in Natural Sciences, 40, pp. 532-568. doi: https:// doi.org/10.1525/hsns.2010.40.4.532

Bosch, R. van den (1989) The Pesticide Conspiracy. Berkeley: University of California Press.

Boudia, S., Creager, A. N. H., Frickel, S., Henry, E., Jas, N., Reinhardt, C. and Roberts, J. A. (2018) "Residues: Rethinking Chemical Environments". Engaging Science, Technology and Society 4, pp. 165-178. doi: https://doi.org/10.17351/ests2018.245

Boudia, S. and Jas, N., ed. (2014) Powerless Science? Science and Politics in a Toxic World. New York: Berghahn Books.

Camprubí Bueno, L. (2017) Los ingenieros de Franco: Ciencia, catolicismo y Guerra Fría en el Estado Franquista. Barcelona: Crítica.

Carter, E. D. (2008) ““'God Bless General Perón”: DDT and the Endgame of Malaria Eradication in Argentina in the 1940s". Journal for the History of Medical and Allied Sciences 64, pp. 78-122. doi: https://doi.org/10.1093/jhmas/jrn057

Clark, J. F. M. (2009) Bugs and the Victorians. New Haven: Yale University Press.

Clarke, S. M. (2012) "Rethinking the post war hegemony of DDT". In: V. Berridge and M. Gorksky, eds., Environment, Health and History. London: Palgrave Macmillan, London, pp. 133-153.

Confidencias de un químico (1947). Barcelona: Iberia.

Conis, E. (2010) "Debating the Health Effects of DDT: Thomas Jukes, Charles Wurster, and the Fate of an Environmental Pollutant". Public Health Rep. 125, pp. 337-342. doi: https://doi. org/10.1177/003335491012500224

Conis, E. (2017) Beyond Silent Spring: An Alternate History of DDT [WWW Document]. Distillations URL: https://www.sciencehistory.org/distillations/beyond-silent-spring-an-alternate-history-of-ddt (accessed 4.22.19).

Cook, G. M. (1998) “'Spray, Spray, Spray!': insecticides and the making of applied entomology in Canada, 1871-1914". Scientia Canadensis 22, pp. 7-50. doi: https://doi.org/10.7202/800406ar

Costa Pinto, A. (2012). The Nature of Fascism Revisited. New York: Boulder.

Dunlap, T. R. (1981) DDT: Scientists, Citizens, and Public Policy. Princeton: Princeton University Press.

Estellés Salarich, J. (1944) La lucha contra el tifus exantemático: despiojamiento. Barcelona: Salvat.

Fernández Astasio, B. (2003) La erradicación del paludismo en España: aspectos biológicos de la lucha antipalúdica. Madrid: Universidad Complutense de Madrid.

Fernández Bravo, S. (2018) Adopción y producción estatal de DDT en México (1940-1980) (TFM). València: Universitat de València.

Fernández Prieto, L. (2007) El apagón tecnológico del franquismo: estado e innovación en la agricultura española del siglo XX. Valencia: Crónica. Tirant lo Blanch.

Fernández Prieto, L., Pan-Montojo, J. and Cabo, M., eds. (2014) Agriculture in the Age of Fascism: Authoritarian Technocracy and Rural Modernization, 1922-1945. Turnhout: Brepols.

Fernández Prieto, L. and Pujol, J. (2001) "El cambio tecnológico en la historia agraria de la España contemporánea". Historia Agraria, 24, pp. 59-86.

Fitzgerald, D. (1986) "Exporting American Agriculture: The Rockefeller Foundation in Mexico, 1943-53". Social Studies of Science 16, pp. 457-483. doi: https://doi. org/10.1177/030631286016003003

Frickel, S., Gibbon, S., Howard, J., Kempner, J., Ottinger, G. and Hess, D. J. (2010) "Undone Science: Charting Social Movement and Civil Society Challenges to Research Agenda Setting”. Science, Technology \& Human Values 35, pp. 444-473. doi: https://doi.org/10.1177/0162243909345836

Frøyen, A. J. (2019) "Influencing for Results: Bees, Beekeepers and Norwegian Pesticide Legislation". HoST -Journal of His- 
tory and Science. Technology 13, pp. 28-50. doi: https://doi. org/10.2478/host-2019-0002

Gaissler, R. P. (2015) The history of environment, science and society told by DDT. A discourse and content analysis of the media from the United States and Brazil between 1944 and 2014. Campinas: Universidade Estadual de Campinas. Instituto de Filosofia e Ciências Humanas.

Gay, H. (2012) "Before and after Silent Spring: From Chemical Pesticides to Biological Control and Integrated Pest Management-Britain, 1945-1980". Ambix 59, pp. 88-108. doi: https:// doi.org/10.1179/174582312X13345259995930

Gomeza Ozámiz, J. M. (1945) "El descubrimiento del nuevo insecticida 666”. Ión 5, pp. 745-750.

González de Molina, M., D. Soto Fernández, y G. Guzmán Casado (2020) The Social Metabolism of Spanish Agriculture, 1900-2008. The Mediterranean Way Towards Industrialization. Cham: Springer Nature Switzerland AG.

Gorostiza, S. (2017) Mobilising nature between democracy and fascism. An environmental history of the Spanish Civil War and the legacies of the Francoist autarky. Coimbra: University of Coimbra.

Griffin, R. (1993) The Nature of Fascism. New York: Routledge.

Griffin, R. (2007) Modernism and Fascism: The Sense of a New Beginning Under Mussolini and Hitler. New York: Palgrave.

Henry, E. (2017) Ignorance scientifique et inaction publique: Les politiques de santé au travail. Paris: Presses de Sciences Po.

Jarman, W. M. and Ballschmiter, K. (2012) "From Coal to DDT: The History of the Development of the Pesticide DDT from Synthetic Dyes till Silent Spring". Endeavour. 36, pp. 131-142. doi: https://doi.org/10.1016/j.endeavour.2012.10.003

Jiménez Lucena, I. (1994) "El tifus exantemático de la posguerra española (1939-1943): el uso de una enfermedad colectiva en la legitimación del 'Nuevo estado'”. Dynamis 14, pp. 185-198.

Lozano Morales, A. (1945) "Problemas prácticos de lucha antipalúdica. Estudio experimental de un nuevo larvicida". Revista de Sanidad e Higiene Pública 19, pp. 413-424.

Mart, M. (2015) Pesticides, a Love Story: America's Enduring Embrace of Dangerous Chemicals. Kansas: University Press of Kansas.

Martín Albaladejo, C. and Sanchiz, B. (2017) "Consequences of the Spanish Civil War for Entomology: A Quantitative Example of Abrupt Alteration in Scientific Research Dynamics”. Isis 108, pp. 335-352. doi: https://doi.org/10.1086/692700

Moreno Martín, F. (1946) "El insecticida español '666”". Ejército, 81 , pp. $59-64$

Murray, D. L. (1994) Cultivating Crisis: The Human Cost of Pesticides in Latin America, 3rd. ed. Austin: University of Texas Press.

Néstor, H. and Roqué, X. (2013) "An Autarkic Science: Physics, Culture, and Power in Franco's Spain”. Historical Studies in the Natural Sciences 43, pp. 202-235. doi: https://doi.org/10.1525/ hsns.2013.43.2.202

Nieto-Galan, A. (2019) The Politics of Chemistry. Science and Power in 20th-Century Spain. Cambridge: Cambridge University Press.

Palmieri, W. (2010) "Environmental imperialism in Sardinia: Pesticides and Politics in the Struggle Against Malaria". In: M. Armiero and M. Hall, eds., Nature and History in Modern Italy, Athens: Ohio University Press, pp. 70-88.

Pan-Montojo, J. (2005) Apostolado, profesión y tecnología: una historia de los ingenieros agrónomos en España. Madrid: Asociación Nacional de Ingenieros Agrónomos.

Paxton, R. O. (2005) Anatomía del fascismo. Barcelona: Península.

Pérez, O. A. (2019) El lindano en España: Visibilidad e invisibilidad de los riesgos tóxicos durante la dictadura franquista. València: Universitat de València. Master thesis.

Pérez, S. (2017) "El Legado de Rachel Carson". Anales de Química, 112 (4), pp. 242-246.

Piédrola Gil, G. (1945) "Trabajos con el DDT. Avances de unas experiencias”. Revista Española de Medicina Colonial 3, pp. 206-223.
Piédrola Gil, G. (1948a) Recientes adquisiciones y técnicas de empleo del DDT. Madrid: Instituto Español de Medicina Colonial.

Piédrola Gil, G. (1948b) "El insecticida sintético DDT en la lucha contra el paludismo". Revista Española de Medicina Colonial 9, pp. 369-405.

Piédrola Gil, G. (1950) Valor y práctica de la moderna desinsectación de la moderna desinsectacion en el ejército español. Madrid: Gráfica Administrativa.

Piédrola Gil, G. (1953a) "El descubrimiento del hexaclorociclohexano". Medicina Colonial 21, pp. 477-494.

Piédrola Gil, G. (1953b) "El descubrimiento del hexaclorociclohexano". Medicina Colonial 22, pp. 139-161.

Piédrola Gil, G. and Matilla Gómez, V. (1947) "Nuevos insecticidas y ahuyentadores: su estudio, importancia y técnicas de empleo". Madrid: Publicaciones del Instituto Español de Medicina Colonial.

Pimentel, D. and Lehman, H. (1993) The Pesticide Question: Environment, Economics, and Ethics. New York: Chapman \& Hall.

Proctor, R.N. and Schiebinger, L., eds. (2008) Agnotology: The Making and Unmaking of ignorance. Stanford: University Press.

Pujol, J., ed. (2001) El pozo de todos los males: sobre el atraso en la agricultura española contemporánea. Barcelona: Crítica.

Quintana Marí, A. (1944) "Contribución al estudio físico-químico del ßßß-tricloro-aabis-(p.clorofenil)-etano y su determinación analítica en los insecticidas preparados a base del mismo". Boletín de Patología Vegetal y Entomología Agrícola 13, pp. 229270.

Quintana Marí, A. and Cid Capella, A. M. (1946) "Una nueva reacción colorimétrica del $\dot{\rho}, \dot{\rho}$ - DDT”. Boletín del Instituto Nacional de Investigaciones Agronómicas 15, pp. 229-251.

Radio Agrícola (1959) "Al habla con nuestros enemigos. El escarabajo de la patata", Boletín de Información del Servicio de Extensión Agrícola 18, pp. 20-21.

Riegert, P. W. (1980) From Arsenic to DDT: A History of Entomology in Western Canada. Toronto: Univ. Toronto Press.

Rodríguez Ocaña, E. (2005) "The birth of the anti-malaria campaign in Spain during the first 30 years of the 20th century: scientific and social aspects". Parassitologia 47, pp. 371-377.

Rodríguez Ocaña, E. (2017) "Tifus y laboratorio en la España de posguerra”. Dynamis. 37, pp. 489-515.

Rodríguez Ocaña, E., Ballester Añón, R., Perdiguero, E., Medina Doménech, R. M. y Molero Mesa, J. (2003) La acción médico-social contra el paludismo en la España metropolitana y colonial del siglo $X X$, Madrid: CSIC

Russell, E. (2001) War and Nature: Fighting Humans and Insects with Chemicals from World War I to Silent Spring. Cambridge: Cambridge University Press.

Sanz Hernando, C. (2016) "Pedro de Lorenzo, de director de La Voz de Castilla a proscrito en Burgos". Historia y comunicación social 21, pp. 497-512. doi: http://dx.doi.org/10.5209/ HICS.54376

Salvá Miquel, J. A. (1947) "Contribución al estudio toxicológico del DDT: influencia de los excipicientes en su absorción percutánea". Trabajos del Instituto Nacional Ciencias Médicas 9, pp. 381-389.

Saraiva, T. (2016) Fascist pigs: technoscientific organisms and the history of Fascism, Inside technology. Cambridge: MIT Press.

Saraiva, T. and Wise, M. N. (2010) "Autarky/Autarchy: Genetics, Food Production, and the Building of Fascism". Historical Studies in Natural Sciences 40, pp. 419-428. doi: https://doi. org/10.1525/hsns.2010.40.4.419

Saz Campos, I. (2004) "Fascism, Fascistization and Developmentalism in Franco's Dictatorship". Social History 29, pp. 342-357. doi: https://doi.org/10.1080/0307102042000257629

Simon, J. (1999) "Naming and Toxicity: A History of Strychnine". Studies in the History and Philosophy of Biology 30, pp. 505525. doi: https://doi.org/10.1016/S1369-8486(98)00031-4

Simpson, J. (1997) La agricultura española (1765-1965), La larga siesta. Madrid: Alianza Editorial. 
Stapleton, D. H. (1998) "The dawn of DDT and its experimental use by the Rockefeller Foundation in Mexico, 1943-1952”. Parassitologia 40, pp. 149-158.

Straumann, L. (2005) Nützliche Schädlinge: angewandte Entomologie, chemische Industrie und Landwirtschaftspolitik in der Schweiz 1874-1952. Zürich: Chronos.

Suryanarayanan, S. and Kleinman, D. L. (2017) Vanishing Bees: Science, Politics, and Honeybee Health. New Brunswick, New Jersey, and London: Rutgers University Press.

Swyngedouw, E. (2015) Liquid Power: Contested Hydro-Modernities in Twentieth-Century Spain. Cambridge: MIT Press.

Vail, D. D. (2012) "Toxic Fables: The Advertising and Marketing of Agricultural Chemicals in the Great Plains, 1945-1985". Endeavour. 36, pp. 165-173. doi: https://doi.org/10.1016/j.endeavour.2012.09.007
Vidal Jordana, J. (1943) "Nota resumen del tifus exantemático en Valencia. Años 1941-1943. Cómo hemos resuelto algunos problemas". Revista de Sanidad e Higiene Pública 17, pp. 571-599.

Vidal Jordana, J. and Rodríguez Fornos, F. (1946) El brote epidémico de tifus exantemático en Valencia, años 1941-1943: consideraciones epidemiológicas. Valencia: Instituto Provincial de Sanidad de Valencia, Valencia.

Vijgen, J., Yi, L. F., Forter, M., Lal, R. and Weber, R. (2006) "The legacy of lindane and technical HCH production". Organohalogen Compounds 68, pp. 898-904.

Whorton, J. (1974) Before Silent Spring: Pesticides and Public Health in pre-DDT America. Princeton: Princeton University Press, Princeton. Wright, A. (2005) The Death of Ramón González: The Modern Agricultural Dilemma. Austin: University of Texas Press. 